\title{
A handwriting method for low-cost gas sensors
}

\author{
F. Loghin ${ }^{1}$, A. Falco ${ }^{2}$, A. Albrecht ${ }^{1}$, J. Salmerón ${ }^{1}$, M. Becherer ${ }^{1}$, P. Lugli ${ }^{2}$, A. Rivandeneyra ${ }^{1}$ \\ ${ }^{1}$ Institute for Nanoelectronics, Technische Universität München, Munich, Germany \\ ${ }^{2}$ Faculty of Science and Technology, Free University of Bozen-Bolzano, Bozen-Bolzano, Italy
}

KEYWORDS. Ball pen, carbon nanotubes, flexible substrate, relative humidity, resistive sensor, silver nanoparticles

\begin{abstract}
In this study, we report on an automated method based on a handwritten technique for the fabrication of low-cost gas sensors based on carbon nanotube (CNT) networks. Taking advantage of the inherent low-cost, flexible and uncomplicated characteristics of pen based techniques and combining them with an automated robotic system allows for high-resolution patterns, high reproducibility and relatively high throughput considering the limitations of parallel processing. To showcase this, gas sensors capable of sensing $\mathrm{NH}_{3}, \mathrm{CO}_{2}, \mathrm{CO}$ and Ethanol as well as temperature and relative humidity are fabricated and characterized displaying competitive performance in relation to previously reported devices. The presented process is compatible with a variety of solutions and inks, and, as such, allowing for an easy integration
\end{abstract}


into existing printing and coating frameworks with the greatest advantage being the ease of creating prototypes due to the non-stringent material requirements.

\section{INTRODUCTION}

The concept of the Internet of Things (IoT) has opened a new paradigm in the interaction between objects and human beings. In the IoT, sensors and actuators are embedded in physical objects and interconnected through wired and wireless networks, creating new opportunities for hardware, software and applications. In this regard, sensors play a fundamental role in extracting valuable information regarding the object and its environment ${ }^{1}$. There have been many advances in the development of sensors with emerging technologies. In particular, flexible and printed electronics are catching the attraction of new sensors developments thanks to the versatility that they offer in terms of new and outstanding features and, therefore, ground-breaking applications ${ }^{2}$. Among these new characteristics are biodegradable materials, large-scale and lowcost processes and self-designed circuits ${ }^{3}$. The most common used manufacturing techniques in this area are inkjet printing and screen printing. The former controls the amount of material deposited with virtually no wastes while defining the pattern and avoids the contact between the substrate and the inkjet head ${ }^{4}$. Whereas the latter technology provides a fast fabrication process with thicker layers although wastes are unavoidable ${ }^{5}$. Although both techniques reduce costs compared to silicon based technology as no clean room, high temperature or vacuum processes are involved, in addition to new materials and fabrication steps being easily integrable, the prototyping costs are still high. There are some examples in the literature were a normal inkjet printer has been used to manufacture circuits ${ }^{6}$. In this regard, a new trend, known as handwriting 
electronics, is catching the attention to fill these gaps ${ }^{7}$. On one hand, commercial pencils have been already employed to define the anode and cathode of paper based fuel cells ${ }^{8}$ and the resistor element of filters ${ }^{9}$. There are also advances in the direction of process-enhanced nanocarbon for integrated logic (PENCILs), broadening the possibilities of conventional graphite-based pencils. PENCILs uses solid composites fabricated by mechanical mixing and subsequent compression into a form similar to a conventional pencil "lead" and these solid composites are then deposited by mechanical abrasion ("drawing") on the surface of paper to generate functional devices ${ }^{10}$. However, this method is limited in throughput, precision, and surface compatibility for interconnects. The inclusion of a posterior step after PENCILs, known as deposition of resistor with abrasion fabrication technique (DRAFT), enhances the obtained throughput, precision, and surface compatibility ${ }^{11}$. On the other hand, fountain pens and ball pens have been used to fabricate electronics by substituting their colour ink by functionalized ones. For example, a light emitting diode (LED) circuit, a chemical sensor ${ }^{12}$ and biocatalytic sensor for home-based low-cost diabetes diagnosis have been reported using these strategies ${ }^{13}$.

With respect to sensors, new materials such as semiconducting metal oxides ${ }^{14}$, graphene oxide ${ }^{15}$, organic materials ${ }^{16}$, and carbon black-polymer composites ${ }^{17}$, have caught lot of attention towards overcoming the drawbacks of conventional gas sensing techniques (i.e. gas chromatography (GC), also coupled to mass spectrometry or atomic emission detection) ${ }^{18}$. One recently quite used material for gas sensors are carbon nanotubes (CNTs). The majority of these CNTbased gas sensors employed more sophisticated techniques, such as sputtering or chemical vapor deposition (CVD), to define this sensing layer, requiring very specific manufacturing conditions and, therefore, resulting in high cost devices ${ }^{19}$. Other commonly used techniques are coating techniques such as drop-casting or spin-coating, limiting the resolution and possibilities of the 
sensors ${ }^{20}$. Furthermore, there are very few examples where the same fabrication technique is used for both electrodes and sensing layer, so that the compatibility among processes plays a larger role thus increasing the final device cost and feasibility ${ }^{11}$. Our solution compromises nonspecial conditions to manufacture, while guaranteeing a high degree of resolution and reliability, employing the same fabrication process for all the layers involved.

In terms of performance, the sensors, which show a relative selective response to other chemical species, possess a functionalized sensing layer ${ }^{20 c, 21}$. Those based only on CNT as the sensor described in this paper exhibit a poor behavior in terms of selectivity ${ }^{19 a, 22}$. Although this is not the purpose of this paper, the selectivity could be enhanced by functionalization of the CNT ink by the addition of metal nanoparticles as shown in ${ }^{23}$. The only requirement of this strategy is that the viscosity of the custom-made ink remains below $10 \mathrm{cp}$.

In this paper we demonstrate how easily an electronic prototype can be realized in a reproducible way by using a ball pen in terms of layout and nominal resistance. In order to provide this reproducibility, the fabrication process is automated through an arm-robot. We designed a resistive gas sensor using this technique. The sensor is drawn on poster foil substrate whose sensing layer is made of CNTs. Previous works have demonstrated the efficiency of this layer for sensing purposes ${ }^{24}$, how it can be defined by printing methods ${ }^{25}$ and how the sensors can be reset in simple and energy-efficient ways ${ }^{26}$. Here, we show how inks with varying solvents and material loads can be employed with a commercial ball-pen to define accurate electronic circuits with a performance comparable to higher cost technologies. Such a solution provides a fast prototyping tool and opens the electronics to the so-called do-it-yourself (DIY) paradigm, providing high resolution and versatility to produce cost-effective sensors. 


\section{MATERIALS AND METHODS}

\section{Device Fabrication}

The devices presented in this manuscript were fabricated with the aid of a ballpoint pen with a sphere diameter of $0.7 \mathrm{~mm}$. The pen and cartridge (Schmidt Technology) are fixated in a 2-stage plotter ( $\mathrm{x}-\mathrm{y}$ axis) with variable height adjustment (z-axis). No extra weight was added and contact force between the pen and substrate consists of the pen's, ink's and holder's weight. Figure 1a displays the writing setup with the pen in contact with the substrate. The movement speed was set at $25 \mathrm{~mm} / \mathrm{s}$. As a substrate, untreated grayback polypropylene (PP) poster foil (EMBLEM) was used. The writing process was performed in ambient lab conditions with no additional heating. For the definition of the contacts, a silver nanoparticle ink (AgNP) (SigmaAldrich) with a load of 30-35 wt $\%$ with a maximum particle size of $50 \mathrm{~nm}$ was used. The ink solvent was triethylene glycol monomethyl ether (TGME). In order to reduce the resistance of the contacts the hatching was performed both at $90^{\circ}$ and $180^{\circ}$ angle. This also reduces the chance of defects as well as any artefacts, which are writing direction dependent. The samples were photonically sintered (Xenon) with a pulse width of $500 \mu$ s and a periodicity of 1 s 15 times following the optimization described in a previous work for the same silver ink ${ }^{27}$. The active area (Figure 1b) was written subsequently using a custom-made CNT ink ${ }^{28}$ with one pass over. The ink consists of $0.03 \mathrm{wt} \%$ CNT (Carbon Solution INC) dispersed with the aid of sodium dodectyl sulphate (SDS) in deionized water $\left(\mathrm{DI} \mathrm{H}_{2} \mathrm{O}\right)$. The sample was submerged in $\mathrm{DI}_{2} \mathrm{O}$ for 10 min to remove the SDS as this acts as a weak insulator as well as shielding the CNTs from the analyte. 


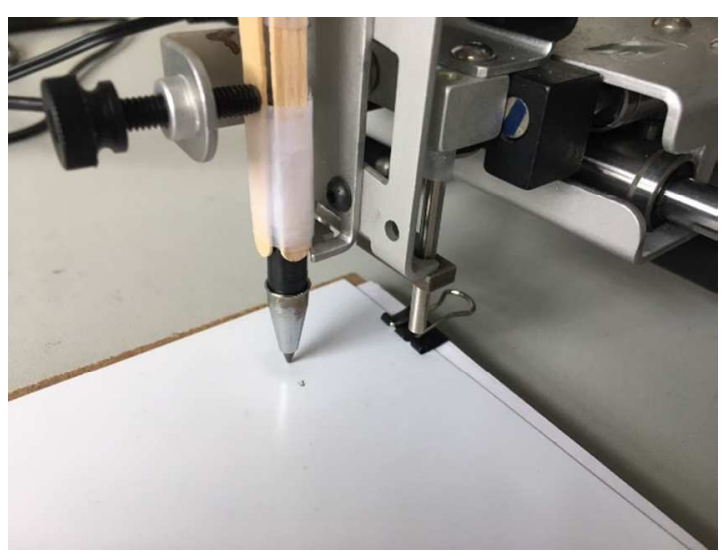

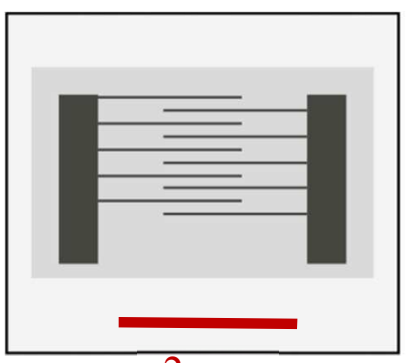

(b)

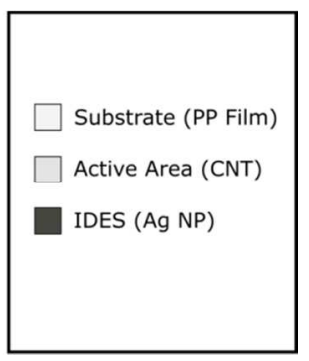

(a)

Figure 1. (a) Photograph of ball pen in the robot arm employed to develop the printed sensor (b) Schematic of the sensor depicting critical layers.

Device Characterization

For the CNT film and AgNP electrode morphology characterization, scanning electron microscopy (SEM) was performed. SEM-images were recorded with a field-emission scanning electron microscope (NVision40 from Carl Zeiss) at an extraction and acceleration voltage of 5 and $7 \mathrm{kV}$, respectively. To optimize the image quality, the working distance was adjusted in the range 5-6 $\mathrm{mm}$.

For the gas measurements, the sample (Figure 2a) was fixed onto a module consisting of a Peltier-heating element used for temperature control, a Pt100 for in-situ temperature monitoring and leads for contacting the sensor (Figure 2b). The holder was inserted into a self-made gas chamber into which gasses can be fluxed (see Figure S2). The sensor response to ammonia $\left(\mathrm{NH}_{3}\right)$, ethanol (Eth) and carbon monoxide $(\mathrm{CO})$ was characterized by exposing the sample to various concentrations of the test gas. In order to maintain a constant flux, a carrier gas $\left(\mathrm{N}_{2}\right)$ was mixed with $\mathrm{NH}_{3}$, Eth or $\mathrm{CO}$ to generate different concentrations. In an analogue manner, carbon dioxide $\left(\mathrm{CO}_{2}\right)$ was mixed with pressurized air to regulate the concentration. A standard 
measurement cycle consists of an active recovery cycle at $60{ }^{\circ} \mathrm{C}$ for $300 \mathrm{~s}$ to recover the sensor to its original state followed by a $300 \mathrm{~s}$ exposure cycle where the test concentration was fluxed. The total flux was kept constant to $200 \mathrm{ml} / \mathrm{min}$. The measurement was automated with the use of LabVIEW 2016, which controls a source meter (Keithley 2602A) for the Pt100 and Peltier element, as well as an impedance analyzer (Keysight E4990A) with an impedance probe kit (4294A1) for the sensor readout. The excitation voltage applied in all measurements was $\mathrm{V}_{\mathrm{DC}}=0$ and $\mathrm{V}_{\mathrm{AC}}=500 \mathrm{mV}$ and the frequency was $20 \mathrm{~Hz}$.

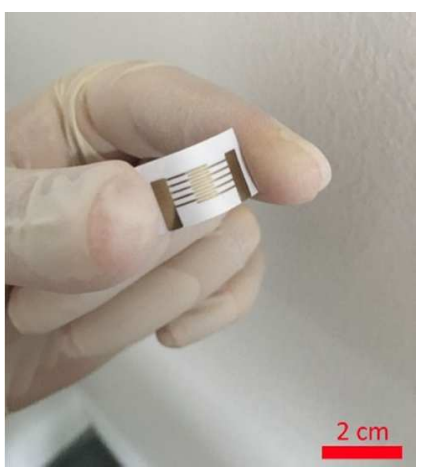

(a)

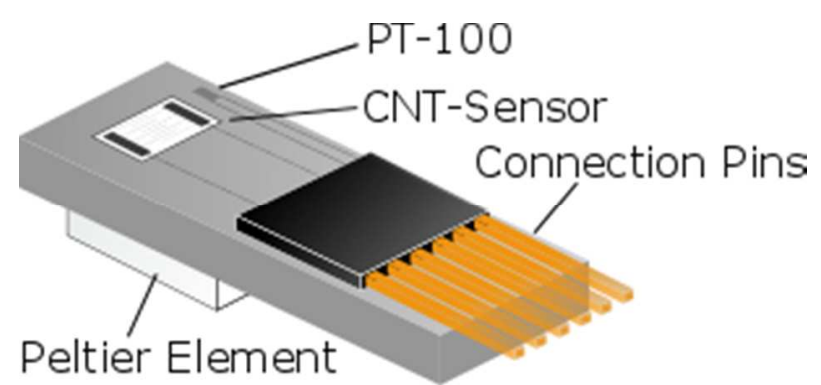

(b)

Figure 2. (a) Photograph of the fabricated sensor; (b) schematic depicting the sensor module

The above-mentioned module was placed in a climatic chamber (VLC4006) with the temperature/humidity control. Monitoring was performed over the climatic chamber sensor system. For the humidity sensing the humidity was ramped up in $15 \%$ steps and held for $600 \mathrm{~s}$. A similar approach was used for the temperature sensing with $5{ }^{\circ} \mathrm{C}$ steps for $300 \mathrm{~s}$. The chamber was filled with ambient air and no conscious effort was made to regulate this.

\section{RESULTS}

The characterization of the deposited films was performed by SEM for a better understanding of the resulting films. From the resulting images of the AgNP films, (Figure 3 (a-b)) a homogeneous film can be observed especially at the $25 \mathrm{kx}$ magnification. Visible is the typical 
necking of the AgNPs that is characteristic to sintered AgNP films ${ }^{27}$. At lower magnification (5kx) microcracks can be observed. Although the precise origin of these cracks needs to be investigated, in the current device architecture, due to the large difference in contribution to the device resistance between contacts and active film, it can be neglected. The CNT films exhibit (Figure $3(\mathrm{c}-\mathrm{d})$ ) a good distribution of CNT across the substrate with a good debundeling visible at higher magnification (200kx).
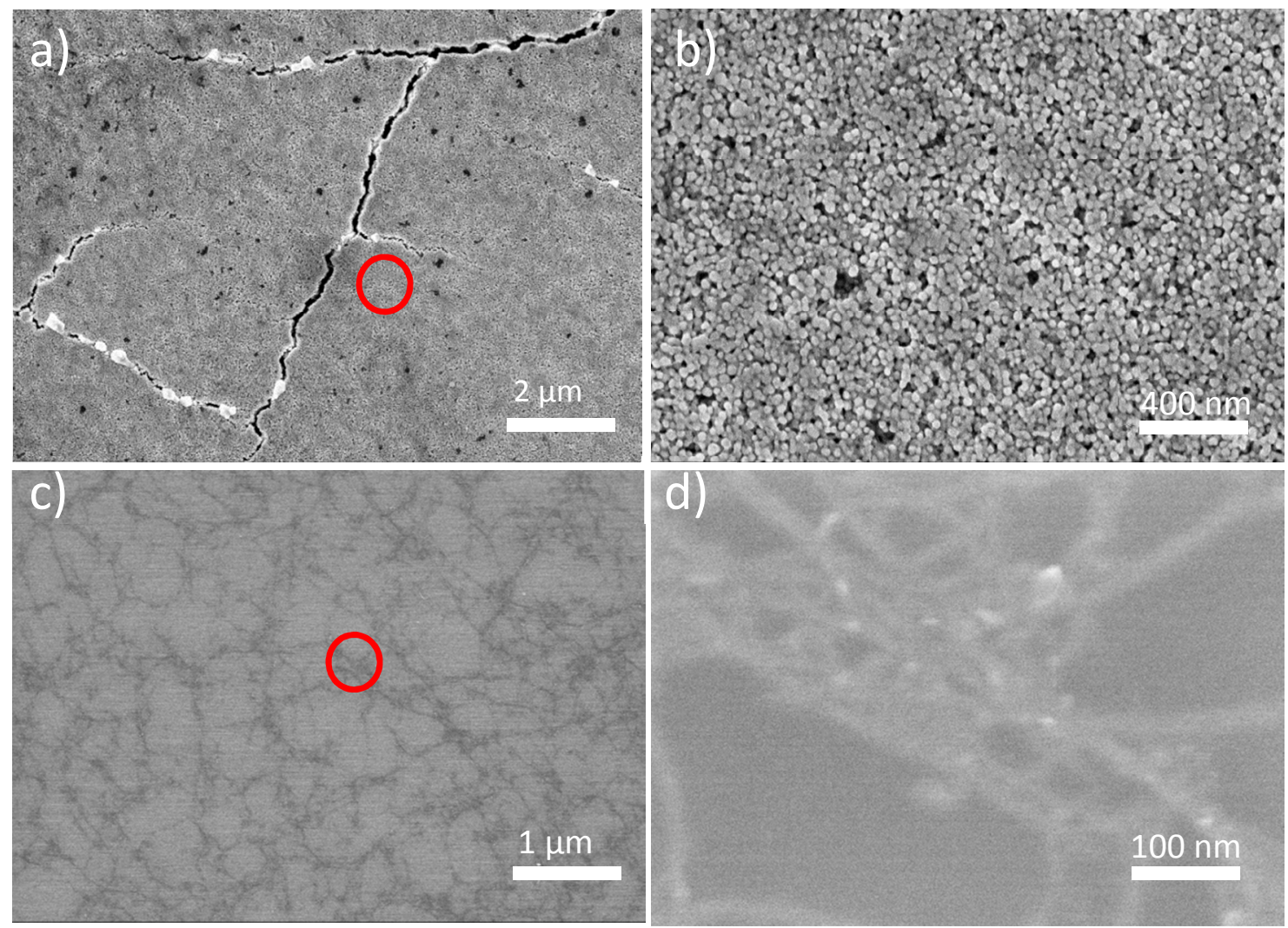

Figure 3. (a-b) Scanning electron microscope image of the silver nanoparticle film at (a) $5 \mathrm{~K}$ (1 $\mu \mathrm{m}$ scale) and (b) $25 \mathrm{~K}$ (200 nm scale bar) magnification with the red circle depicting the higher magnification region. (c-d) ) Scanning electron microscope image of the CNT film at (a) 20K (1 $\mu \mathrm{m}$ scale) and (b) 200K (100 $\mathrm{nm}$ scale bar) magnification with the red circle depicting the higher magnification region. 
A set of 20 sensors was written with a nominal value of resistance measure at ambient conditions of $1.6 \pm 0.3 \mathrm{k} \Omega$. In all cases the phase of the devices was below $-5 \cdot 10^{-4} \mathrm{o}$, indicating the pure resistive behaviour of our sensors.

The sensor performance was evaluated by its normalized response, defined in (1) as the relative change in resistance with respect to its initial value,

$$
\text { Norm. Resistance }(\%)=\frac{R_{f}-R_{i}}{R_{i}} \cdot 100
$$

where $R_{i}$ and $R_{f}$ are the initial and final resistance values of an exposure cycle, respectively. Figure 4 illustrates the characterization of the sensor towards $\mathrm{NH}_{3}$. Higher temperatures were not considered to avoid the degradation of the substrate. Figure 4 a shows the calibration curve of the sensor for $\mathrm{NH}_{3}$.

In comparison with other printed gas sensors based on CNTs as sensing material, the response of the developed sensors is consistent. In the cases of the studied gases, the resistance of the sensor increases when it is exposed to any of them. The same trend is observed when the sensor is under increasing content of moisture. In contrast to this, the resistance value decreases when the sensor is analysed with increases in temperature ${ }^{29}$. 

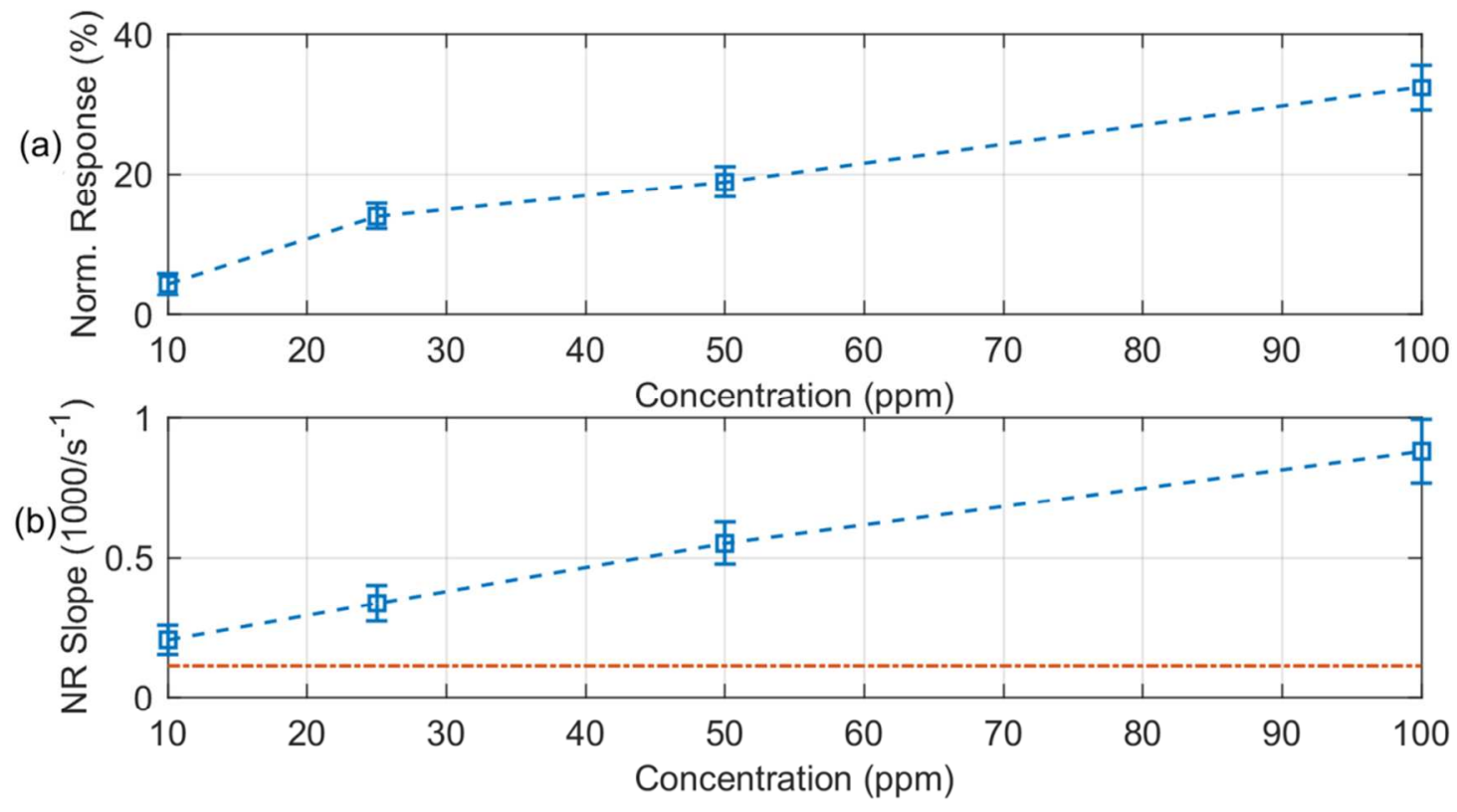

Figure 4. Response to $\mathrm{NH}_{3}$ (a) Normalized resistance vs. concentration; (b) Average slope of the normalized response in the first $150 \mathrm{~s}$ of exposure. The red dashed line indicates the average slope of the normalized response in the last $150 \mathrm{~s}$ of cooling time.

In particular, the response to $\mathrm{NH}_{3}$ is much higher than the change obtained towards the other gases. For example, the normalized variation in resistance at $50 \mathrm{ppm}$ of ammonia is about $20 \%$, whereas the change at $50 \mathrm{ppm}$ ethanol is about 7\% (Figure 5c) and this variation is about $4.5 \%$ for $\mathrm{CO}$ (Figure $5 \mathrm{~b}$ ). In the case of $\mathrm{CO}_{2}$, the measured concentrations are much higher because the normal air used as carrier gas typically contains $390 \mathrm{ppm}$ of $\mathrm{CO}_{2}$, which is the reason for the high concentration range covered in our tests (Figure 5a). 
(a)
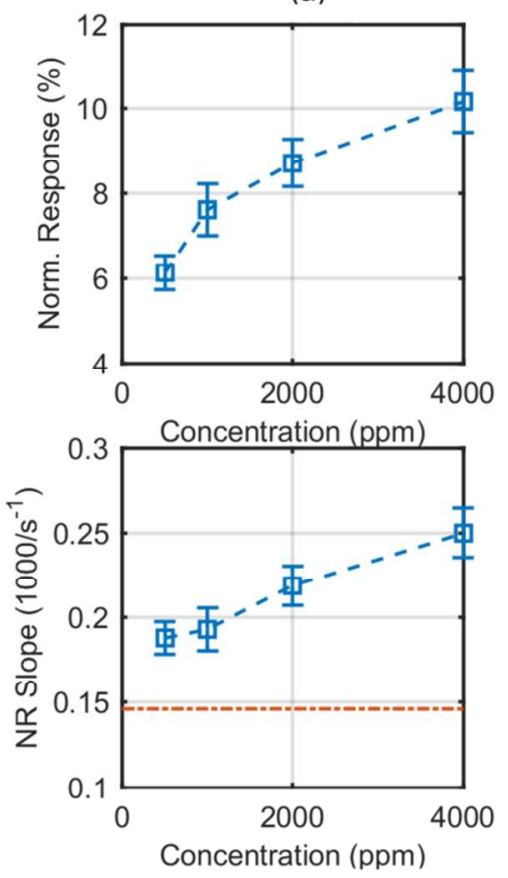

(b)
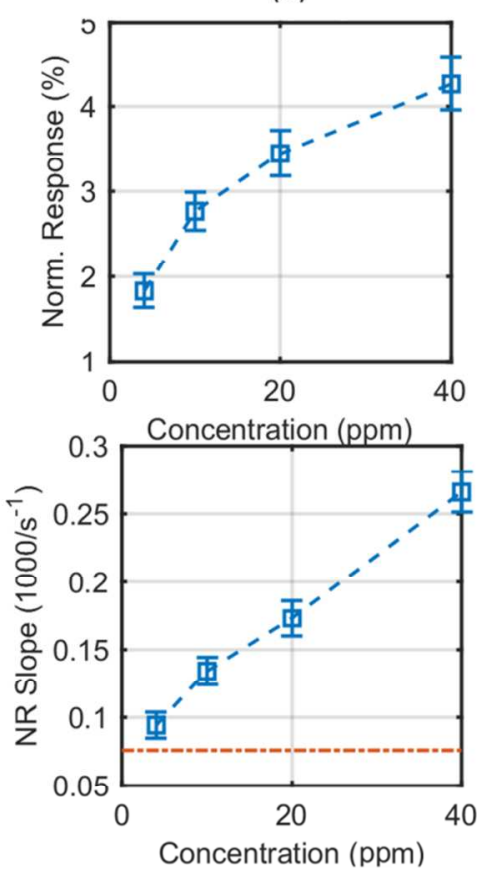

(c)
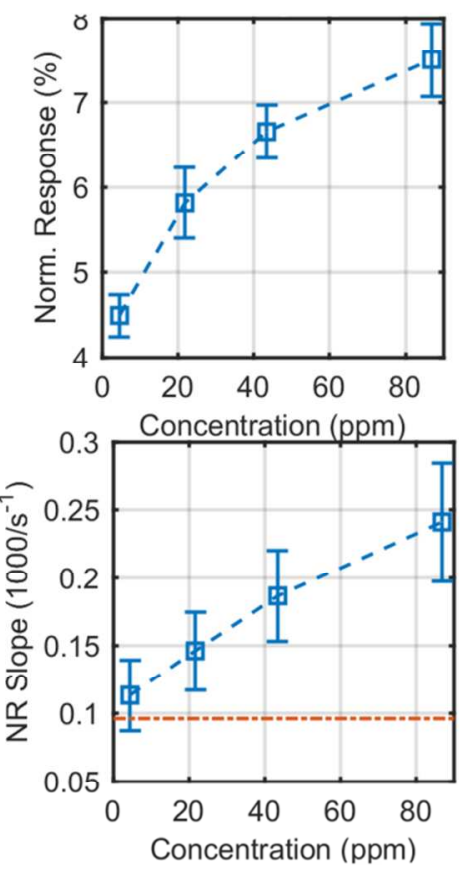

Figure 5. First row corresponds to the normalized resistance, bottom row to average slope of the normalized response in the first $150 \mathrm{~s}$ of exposure vs. concentration for (a) $\mathrm{CO}_{2}$, (b) $\mathrm{CO}$ and (c) Ethanol. In the bottom row the red dashed line indicates the average slope of the normalized response in the last $150 \mathrm{~s}$ of cooling time.

With respect to the response of the sensor to moisture content (Figure 6a), the variation in resistance also shows a direct increase with the humidity level, with a variation above $30 \%$ at $90 \%$ RH. Looking at the behaviour with temperature (Figure 6b), the resistance decreases with the increase in temperature, as expected because temperature facilitates the carriers to cross the barriers at the junctions. Notice that the ambient conditions were set at $25 \% \mathrm{RH}$ and $25^{\circ} \mathrm{C}$. 
(a)

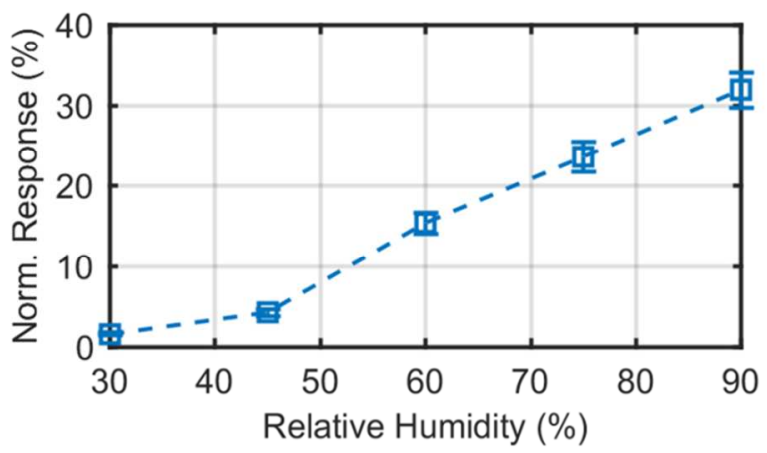

(b)

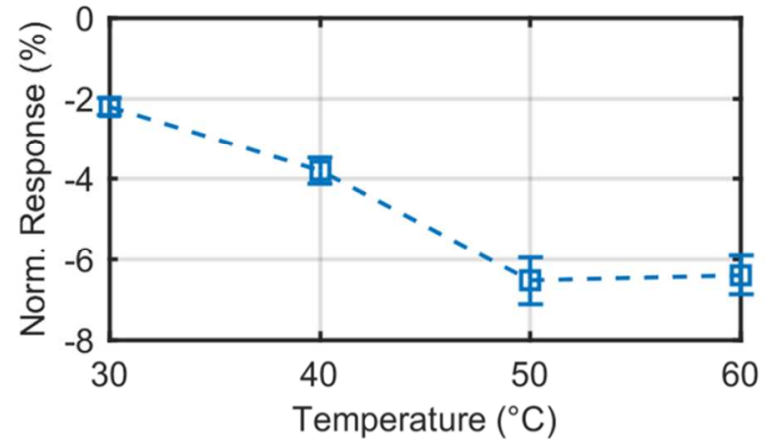

Figure 6. Normalized resistance vs. concentration for (a) RH and (b) Temperature.

Table 1 summarizes the performance of the device with respect to each parameter studied to facilitate comparison.

Table 1. Summary of the main features of developed sensor response. NR stands for Normalized resistance

\begin{tabular}{|l|l|l|l|l|l|}
\hline Parameter & Range & Sensitivity & Recovery $\left({ }^{\circ} \mathrm{C}\right)$ & $\begin{array}{l}\text { Exposure } \\
\text { Time }(\mathrm{s})\end{array}$ & $\begin{array}{l}\text { Linearity } \\
\left(\mathrm{R}^{2}\right)\end{array}$ \\
\hline $\mathrm{NH}_{3}$ & $10-100 \mathrm{ppm}$ & $0.3 \% \mathrm{NR} / \mathrm{ppm}$ & $60(300 \mathrm{~s})$ & 300 & 0.9642 \\
\hline $\mathrm{CO}$ & $5-45 \mathrm{ppm}$ & $0.06 \% \mathrm{NR} / \mathrm{ppm}$ & $60(300 \mathrm{~s})$ & 300 & 0.9169 \\
\hline Ethanol & $5-80 \mathrm{ppm}$ & $0.03 \% \mathrm{NR} / \mathrm{ppm}$ & $60(300 \mathrm{~s})$ & 300 & 0.8996 \\
\hline $\mathrm{CO}_{2}$ & $500-4000 \mathrm{ppm}$ & $0.011 \% \mathrm{NR} / \mathrm{ppm}$ & $60(300 \mathrm{~s})$ & 300 & 0.9182 \\
\hline $\mathrm{RH}$ & $30-90 \%$ & $0.5 \% \mathrm{NR} / \% \mathrm{RH}$ & $60(600 \mathrm{~s})$ & 600 & 0.9768 \\
\hline Temperature & $30-65^{\circ} \mathrm{C}$ & $\begin{array}{l}-0.217 \% \mathrm{NR} /{ }^{\circ} \mathrm{C} \\
30<\mathrm{T}<50{ }^{\circ} \mathrm{C} \\
\mathrm{No} \mathrm{sensitivity}^{\mathrm{T}}>50^{\circ} \mathrm{C}\end{array}$ & - & 600 & 0.9775 \\
\hline
\end{tabular}

DISCUSSION 
Our sensor shows a $5 \% \mathrm{NR}$ at $10 \mathrm{ppm}$ and $20 \% \mathrm{NR}$ at $50 \mathrm{ppm} \mathrm{NH}_{3}$ values very similar to previous developed devices (see Table 2). Nevertheless, the advantages of our approach provides high value to our sensor: the CNT layer did not required any functionalization, the fabrication process is low-cost using the same procedure to define all the layers and it is done at room conditions without special requirements. Furthermore, the sensor is defined on a flexible and biodegradable substrate, resulting in conformally-shaped devices and reducing wastes.

In the case of $\mathrm{CO}_{2}$, as commented before, we could not test the sensor at lower concentrations due to constrains in the setup. However, our sensor exhibits almost $8 \% \mathrm{NR}$ at $1000 \mathrm{ppm}$, which is very similar to the response of Lin et al. $2016^{30}$. With respect to CO, we tested very low concentrations in comparison with other CO sensors based on CNTs and our device presents a higher response than those examples (see Table 2). For moisture content, the sensor described in this work shows about $18 \% \mathrm{NR}$ at $60 \% \mathrm{RH}$ and about $32 \% \mathrm{NR}$ at $90 \% \mathrm{RH}$. Again, this response is comparable to previous works, proving that this technique offers the same performance as sophisticated fabrication methods.

It must be highlighted the fact that the majority of the authors do not study the response of their devices with respect to other gas species or environmental parameters, and therefore, the selectivity or the behavior of the sensor under real working conditions is not tested as illustrated in this work. It is clear that our device requires some kind of functionalization or treatment to achieve a better selectivity but it has been already proved that the decoration of CNTs with metal nanoparticles enhanced the selectivity of CNT-based gas sensors ${ }^{23,31}$. Furthermore, the use of sensor arrays for multicomponent analysis using multivariate calibration software can achieve improved analyte sensitivity.

Table 2. Summary of developed gas sensors based on CNTs. All the sensors are resistive. 


\begin{tabular}{|c|c|c|c|c|c|}
\hline Reference & $\begin{array}{l}\text { Fabrication } \\
\text { method }\end{array}$ & Sensing layer & Gas & Sensitivity & Range \\
\hline $\begin{array}{l}\text { Schütt et al } \\
2017^{19 b}\end{array}$ & $\begin{array}{c}\text { Glass substrate, } \\
\text { patterned } \\
\text { contacts }\end{array}$ & $\begin{array}{c}\text { Single and Networked } \\
\text { ZnO-CNT }\end{array}$ & $\mathrm{NH}_{3}$ & $6.4 \mathrm{NR} \% / \mathrm{ppm}$ & $\begin{array}{c}10-100 \\
\text { ppm }\end{array}$ \\
\hline $\begin{array}{l}\text { Hester et } \\
\text { al. } 2015^{22 a}\end{array}$ & $\begin{array}{l}\text { Kapton substrate, } \\
\text { Graphene oxide } \\
\text { electrodes inkjet } \\
\text { printing }\end{array}$ & $\begin{array}{l}\text { single wall CNTs } \\
\text { (SWCNTs) }\end{array}$ & $\mathrm{NH}_{3}$ & $\begin{array}{c}2.8 \% \mathrm{NR} \text { at } 10 \\
\mathrm{ppm}\end{array}$ & $10 \mathrm{ppm}$ \\
\hline $\begin{array}{l}\text { Mirica et } \\
\text { al. } 2012^{11}\end{array}$ & $\begin{array}{l}\text { Handwriting } \\
\text { DRAWN }\end{array}$ & CNT and graphite & $\mathrm{NH}_{3}$ & $\begin{array}{c}1.8 \% \mathrm{NR} \text { at } 10 \\
\mathrm{ppm}\end{array}$ & $\begin{array}{l}1-10 \\
\text { ppm }\end{array}$ \\
\hline $\begin{array}{l}\text { Eising et } \\
\text { al. } 2017^{21 \mathrm{a}}\end{array}$ & $\begin{array}{l}\text { Silicon substrate, } \\
\text { sputtering } \\
\text { electrodes }\end{array}$ & $\begin{array}{l}\text { PANI: multi wall CNTs } \\
\text { (MWCNTs) films }\end{array}$ & $\mathrm{NH}_{3}$ & $\begin{array}{c}40 \% \mathrm{NR} \text { at } 30 \\
\mathrm{ppm}\end{array}$ & $\begin{array}{c}30-60 \\
\text { ppm }\end{array}$ \\
\hline This work & Pen ball & SWCNT & $\mathrm{NH}_{3}$ & $\begin{array}{c}20 \% \mathrm{NR} \text { at } 50 \\
\mathrm{ppm}\end{array}$ & $\begin{array}{c}10-100 \\
\text { ppm }\end{array}$ \\
\hline $\begin{array}{l}\text { Ellis et al. } \\
2016^{21 b}\end{array}$ & $\begin{array}{l}\text { Silicon substrate, } \\
\text { drop casting }\end{array}$ & $\mathrm{In}_{2} \mathrm{O}_{3} / \mathrm{SWCNT}$ & Ethanol & $\begin{array}{l}0.1285 \% \mathrm{NR} / \mathrm{ppm} \\
\text { log. Response }\end{array}$ & $\begin{array}{c}1-100 \\
\mathrm{ppm}\end{array}$ \\
\hline $\begin{array}{l}\text { Zhang et } \\
\text { al. } 2014^{32}\end{array}$ & $\begin{array}{l}\text { layer-by-layer } \\
\text { self-assembly }\end{array}$ & (MWCNTs)/polymer & Ethanol & $\begin{array}{l}4 \% \mathrm{NR} \text { at } \\
30 \mathrm{kppm}\end{array}$ & $\begin{array}{l}1 \mathrm{kppm}- \\
30 \mathrm{k} \mathrm{ppm}\end{array}$ \\
\hline This work & Pen ball & SWCNT & Ethanol & $6 \% \mathrm{NR}$ at $20 \mathrm{ppm}$ & $\begin{array}{l}5-80 \\
\text { ppm }\end{array}$ \\
\hline $\begin{array}{l}\text { Liu et al. } \\
2016^{20 \mathrm{a}}\end{array}$ & $\begin{array}{l}\text { Drop-casting on } \\
\text { glass evaporated } \\
\text { electrodes }\end{array}$ & $\begin{array}{c}\text { organocobalt complex } \\
\text { and SWCNT }\end{array}$ & $\mathrm{CO}$ & $\begin{array}{l}1.2 \% \mathrm{NR} \text { at } \\
3 \mathrm{kppm}\end{array}$ & $\begin{array}{c}800-6000 \\
\text { ppm }\end{array}$ \\
\hline $\begin{array}{l}\text { Hannon et } \\
\text { al. } 2014^{22 b}\end{array}$ & Silicon wafer & SWCNT & $\mathrm{CO}$ & $\begin{array}{c}0.0023 \% \mathrm{NR} / \mathrm{ppm} \\
\text { Exp. Response }\end{array}$ & $\begin{array}{l}1-60 \\
\text { ppm }\end{array}$ \\
\hline This work & Pen ball & SWCNT & $\mathrm{CO}$ & $\begin{array}{c}3.5 \% \mathrm{NR} \text { at } 20 \\
\mathrm{ppm}\end{array}$ & $\begin{array}{l}5-45 \\
\text { ppm }\end{array}$ \\
\hline $\begin{array}{l}\text { Young et } \\
\text { al. } 2017^{19 a}\end{array}$ & $\begin{array}{l}\text { CNTs grown by } \\
\text { CVD transferred } \\
\text { to a flexible one }\end{array}$ & CNT & $\mathrm{CO}_{2}$ & $1 \% \mathrm{NR}$ at $50 \mathrm{ppm}$ & $\begin{array}{c}50-800 \\
\text { ppm }\end{array}$ \\
\hline $\begin{array}{l}\text { Lin et al. } \\
2016^{30}\end{array}$ & $\begin{array}{l}\text { CNTs grown by } \\
\text { CVD transferred } \\
\text { to a flexible one }\end{array}$ & Au coated MWCNTs & $\begin{array}{l}\mathrm{CO}_{2} \\
\mathrm{NH}_{3}\end{array}$ & $\begin{array}{c}4.8 \% \mathrm{NR} \text { at } 800 \\
\mathrm{ppm} \mathrm{CO}_{2} \\
5.2 \% \mathrm{NR} \text { at } 800 \\
\text { ppm } \mathrm{NH}_{3}\end{array}$ & $\begin{array}{c}50-800 \\
\text { ppm }\end{array}$ \\
\hline
\end{tabular}




\begin{tabular}{|c|c|c|c|c|c|}
\hline This work & Pen ball & SWCNT & $\mathrm{CO}_{2}$ & $\begin{array}{c}8 \% \mathrm{NR} \text { at } 1000 \\
\mathrm{ppm}\end{array}$ & $\begin{array}{c}500-4000 \\
\mathrm{ppm}\end{array}$ \\
\hline $\begin{array}{c}\text { Jung et al. } \\
2014^{20 \mathrm{~b}}\end{array}$ & spin-coating & MWCNTs & $\mathrm{RH}$ & $\begin{array}{c}60 \% \mathrm{NR} \text { at } \\
60 \% \mathrm{RH}\end{array}$ & $10-90 \%$ \\
\hline $\begin{array}{c}\text { Jung et al. } \\
2015^{20 \mathrm{c}}\end{array}$ & spin-coating & CNT/MnO 2 & $\mathrm{RH}$ & $\begin{array}{c}60 \% \mathrm{NR} \text { at } \\
90 \% \mathrm{RH}\end{array}$ & $10-90 \%$ \\
\hline $\begin{array}{c}\text { Zhao et al. } \\
2017^{33}\end{array}$ & $\begin{array}{c}\text { Commercial } \\
\text { pencil and ink } \\
\text { marker }\end{array}$ & Oxidized MWCNT & $\mathrm{RH}$ & $18-33 \%\left(\Delta \mathrm{I} / \mathrm{I}_{0}\right)$ & $\begin{array}{c}33- \\
90 \% \mathrm{RH}\end{array}$ \\
\hline $\begin{array}{c}\text { This work } \\
\text { Pen ball }\end{array}$ & SWCNT & $\mathrm{RH}$ & $20 \% \mathrm{NR}$ at \\
$60 \% \mathrm{RH}$ & $\begin{array}{c}30- \\
90 \mathrm{RH}\end{array}$ \\
\hline $\begin{array}{c}\text { Honda et } \\
\text { al. } 2014^{34}\end{array}$ & $\begin{array}{c}\text { Shadow mask } \\
\text { printing on } \\
\text { kapton }\end{array}$ & PEDOT:PSS and CNTs & Temperature & $0.6 \% \mathrm{NR} /{ }^{\circ} \mathrm{C}$ & $20-50{ }^{\circ} \mathrm{C}$ \\
\hline $\begin{array}{c}\text { This work } \\
\text { Pen ball }\end{array}$ & SWCNT & Temperature & $-4 \% \mathrm{NR}$ at $40{ }^{\circ} \mathrm{C}$ & $30-65^{\circ} \mathrm{C}$ \\
\hline
\end{tabular}

Finally, in order to assess the long-term stability of the sensor, we performed an analysis of the sensitivity comparing the normalized response one day after fabrication and one year after fabrication. The sensors were kept in a kitchen room, exposed to air, light and all the environmental agents, which would interact with them during their normal employment as airquality sensors. Figure 7 shows how, besides the lowest part of the normalized response curve, the evaluated response after one year is very consistent with freshly fabricated sensors. 


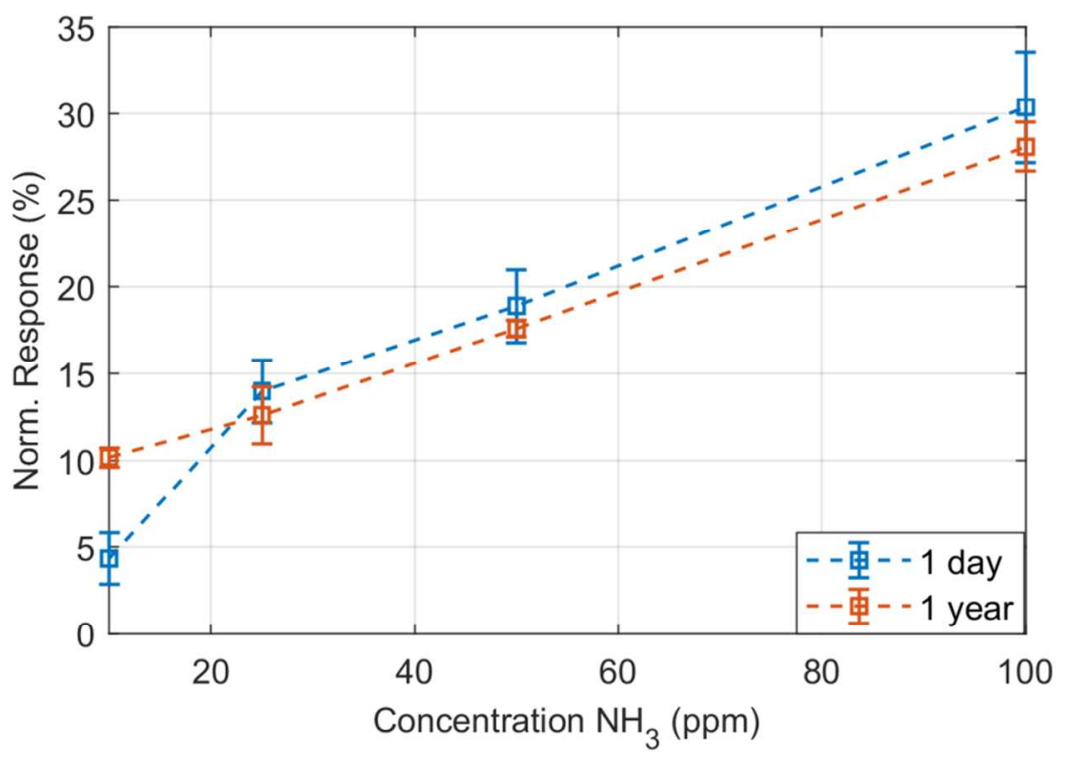

Figure 7. Normalized response with respect to different concentrations of $\mathrm{NH}_{3}$ for the same sensor one day after fabrication (blue line) and one year after fabrication (orange line).

\section{CONCLUSIONS}

In this paper, we introduced a low cost fabrication technique based on a hand writing method (ballpoint pen) which allows for fast prototyping as well as do-it yourself electronics. In particular, we extended the inherent advantages of the existing technique by incorporating it into an automated robotic system that allows for high-resolution patterns, high reproducibility and relatively high throughput considering the limitations of parallel processing. Such characteristics had not previously been achieved with handwritten electronics. The process here highlighted is compatible with both commercial and custom-made inks providing versatile and flexible manufacturing, allowing for the incorporation into existing printing and coating frameworks. As a proof of concept, a sensing element was developed able to detect $\mathrm{NH}_{3}, \mathrm{CO}_{2}, \mathrm{CO}$ and Ethanol in a controlled environment, delivering comparable results to previously reported devices realized 
with significantly more sophisticated techniques. The sensor was also characterized with respect to relative humidity as well as temperature to account for cross sensitivity to changing environmental conditions.

\section{AUTHOR INFORMATION}

\section{Corresponding Author}

Dr.-Ing. Almudena Rivadeneyra

Institute for Nanoelectronics, Technische Universität München

Theresienstrasse 90, 80333 Munich, Germany

Email: almudena.rivadeneyra@tum.de

\section{Author Contributions}

The manuscript was written through contributions of all authors. All authors have given approval to the final version of the manuscript.

\section{ACKNOWLEDGMENT}

This work was partially funded by the TUM Graduate School.

\section{REFERENCES}

1. Chui, M.; Löffler, M.; Roberts, R., The Internet of Things. McKinsey Quarterly 2010, 2 (2010), 1-9. 
2. (a) Fernández-Salmerón, J.; Rivadeneyra, A.; Martínez-Martí, F.; Capitán-Vallvey, L. F.; Palma, A. J.; Carvajal, M. A., Passive UHF RFID Tag with Multiple Sensing Capabilities. Sensors 2015, 15 (10), 26769-26782; (b) Mattana, G.; Briand, D., Recent Advances in Printed Sensors On Foil. Materials Today 2016, 19 (2), 88-99; (c) Rivadeneyra, A.; FernándezSalmerón, J.; Agudo-Acemel, M.; López-Villanueva, J. A.; Capitan-Vallvey, L. F.; Palma, A. J., Printed Electrodes Structures As Capacitive Humidity Sensors: A Comparison. Sensors and Actuators A: Physical 2016, 244, 56-65; (d) Alkin, K.; Stockinger, T.; Zirkl, M.; Stadlober, B.; Bauer-Gogonea, S.; Kaltenbrunner, M.; Bauer, S.; Müller, U.; Schwödiauer, R., Paper-based Printed Impedance Sensors for Water Sorption And Humidity Analysis. Flexible and Printed Electronics 2017, 2 (1), 014005.

3. Suganuma, K., Introduction to printed electronics. Springer Science \& Business Media: 2014; Vol. 74.

4. Calvert, P., Inkjet printing For Materials and Devices. Chemistry of Materials 2001, 13 (10), 3299-3305.

5. Parashkov, R.; Becker, E.; Riedl, T.; Johannes, H.-H.; Kowalsky, W., Large Area Electronics Using Printing Methods. Proceedings of the IEEE 2005, 93 (7), 1321-1329.

6. (a) Lee, H.-H.; Chou, K.-S.; Huang, K.-C., Inkjet printing of nanosized silver colloids. Nanotechnology 2005, 16 (10), 2436; (b) Kawahara, Y.; Hodges, S.; Cook, B. S.; Zhang, C.; Abowd, G. D. In Instant inkjet circuits: lab-based inkjet printing to support rapid prototyping of UbiComp devices, Proceedings of the 2013 ACM international joint conference on Pervasive and ubiquitous computing, ACM: 2013; pp 363-372; (c) Tortorich, R. P.; Choi, J.-W., Inkjet printing of carbon nanotubes. Nanomaterials 2013, 3 (3), 453-468. 
7. Li, Z.; Liu, H.; Ouyang, C.; Hong Wee, W.; Cui, X.; Jian Lu, T.; Pingguan $\square$ Murphy, B.; Li, F.; Xu, F., Recent Advances in Pen $\square$ Based Writing Electronics and their Emerging Applications. Advanced Functional Materials 2016, 26 (2), 165-180.

8. $\quad$ Dossi, N.; Toniolo, R.; Piccin, E.; Susmel, S.; Pizzariello, A.; Bontempelli, G., Pencil $\square$ Drawn Dual Electrode Detectors to Discriminate Between Analytes Comigrating on Paper $\square$ Based Fluidic Devices but Undergoing Electrochemical Processes with Different Reversibility. Electroanalysis 2013, 25 (11), 2515-2522.

9. Kurra, N.; Dutta, D.; Kulkarni, G. U., Field Effect Transistors and RC Filters from Pencil-trace on Paper. Physical Chemistry Chemical Physics 2013, 15 (21), 8367-8372.

10. (a) Mirica, K. A.; Azzarelli, J. M.; Weis, J. G.; Schnorr, J. M.; Swager, T. M., Rapid Prototyping of Carbon-Based Chemiresistive Gas Sensors on Paper. Proceedings of the National Academy of Sciences 2013, 110 (35), E3265-E3270; (b) Frazier, K. M.; Mirica, K. A.; Walish, J. J.; Swager, T. M., Fully-drawn Carbon-based Chemical Sensors on Organic and Inorganic Surfaces. Lab on a Chip 2014, 14 (20), 4059-4066; (c) Mitchell, H. T.; Noxon, I. C.; Chaplan, C. A.; Carlton, S. J.; Liu, C. H.; Ganaja, K. A.; Martinez, N. W.; Immoos, C. E.; Costanzo, P. J.; Martinez, A. W., Reagent Pencils: a New Technique for Solvent-free Deposition of Reagents onto Paper-based Microfluidic Devices. Lab on a Chip 2015, 15 (10), 2213-2220.

11. Mirica, K. A.; Weis, J. G.; Schnorr, J. M.; Esser, B.; Swager, T. M., Mechanical Drawing of Gas Sensors on Paper. Angewandte Chemie International Edition 2012, 51 (43), 10740-10745.

12. Han, J.-W.; Kim, B.; Li, J.; Meyyappan, M., Carbon Nanotube Ink for Writing on Cellulose Paper. Materials Research Bulletin 2014, 50, 249-253. 
13. Bandodkar, A. J.; Jia, W.; Ramírez, J.; Wang, J., Biocompatible Enzymatic Roller Pens for Direct Writing of Biocatalytic Materials:“Do $\square$ it $\square$ Yourself” Electrochemical Biosensors. Advanced healthcare materials 2015, 4 (8), 1215-1224.

14. Su, J.-J.; Beardslee, L.; Brand, O. In Combined chemoresistive and chemocapacitive microsensor structures, Solid-State Sensors, Actuators and Microsystems (TRANSDUCERS \& EUROSENSORS XXVII), 2013 Transducers \& Eurosensors XXVII: The 17th International Conference on, IEEE: 2013; pp 258-261.

15. Zhang, D.; Tong, J.; Xia, B., Humidity-sensing Properties of Chemically Reduced Graphene Oxide/Polymer Nanocomposite Film Sensor Based on Layer-by-Layer Nano SelfAssembly. Sensors and Actuators B: Chemical 2014, 197, 66-72.

16. Zampetti, E.; Pantalei, S.; Muzyczuk, A.; Bearzotti, A.; De Cesare, F.; Spinella, C.; Macagnano, A., A high Sensitive NO2 Gas Sensor Based on PEDOT-PSS/TiO2 Nanofibres. Sensors and Actuators B: Chemical 2013, 176, 390-398.

17. Rivadeneyra, A.; Fernández-Salmerón, J.; Agudo-Acemel, M.; López-Villanueva, J. A.; Capitán-Vallvey, L. F.; Palma, A. J., Hybrid Printed Device for Simultaneous Vapors Sensing. IEEE Sensors Journal 2016, 16 (23), 8501-8508.

18. Ge, X.; Kostov, Y.; Rao, G., Low $\square$ Cost Noninvasive Optical CO2 Sensing System for Fermentation and Cell Culture. Biotechnology and bioengineering 2005, 89 (3), 329-334.

19. (a) Young, S.-J.; Lin, Z.-D., Sensing Performance of Carbon Dioxide Gas Sensors with Carbon Nanotubes on Plastic Substrate. ECS Journal of Solid State Science and Technology 2017, 6 (5), M72-M74; (b) Schütt, F.; Postica, V.; Adelung, R.; Lupan, O., Single and 
Networked ZnO-CNT Hybrid Tetrapods for Selective Room-Temperature High-Performance Ammonia Sensors. ACS Applied Materials \& Interfaces 2017, 9 (27), 23107-23118.

20. (a) Liu, S. F.; Lin, S.; Swager, T. M., An Organocobalt-Carbon Nanotube Chemiresistive Carbon Monoxide Detector. ACS sensors 2016, 1 (4), 354-357; (b) Jung, D.; Han, M.; Lee, G. S., Humidity-sensing Characteristics of Multi-Walled Carbon Nanotube Sheet. Materials Letters 2014, 122, 281-284; (c) Jung, D.; Kim, J.; Lee, G. S., Enhanced humidity-sensing response of metal oxide coated carbon nanotube. Sensors and Actuators A: Physical 2015, 223, 11-17.

21. (a) Eising, M.; Cava, C. E.; Salvatierra, R. V.; Zarbin, A. J. G.; Roman, L. S., Doping Effect on Self-Assembled Films of Polyaniline and Carbon Nanotube Applied as Ammonia Gas Sensor. Sensors and Actuators B: Chemical 2017, 245, 25-33; (b) Ellis, J. E.; Star, A., Carbon Nanotube $\square$ based Gas Sensors toward Breath Analysis. ChemPlusChem 2016.

22. (a) Hester, J. G.; Tentzeris, M. M.; Fang, Y. In Inkjet-printed, flexible, high performance, carbon nanomaterial based sensors for ammonia and DMMP gas detection, Microwave Conference (EuMC), 2015 European, IEEE: 2015; pp 857-860; (b) Hannon, A.; Lu, Y.; Li, J.; Meyyappan, M., Room Temperature Carbon Nanotube Based Sensor for Carbon Monoxide Detection. Journal of Sensors and Sensor Systems 2014, 3 (2), 349.

23. Abdelhalim, A.; Winkler, M.; Loghin, F.; Zeiser, C.; Lugli, P.; Abdellah, A., Highly Sensitive and Selective Carbon Nanotube-Based Gas Sensor Arrays Functionalized with Different Metallic Nanoparticles. Sensors and Actuators B: Chemical 2015, 220, 1288-1296.

24. Contés-de Jesús, E.; Li, J.; Cabrera, C. R., Latest Advances in Modified/Functionalized Carbon Nanotube-Based Gas Sensors. 2013. 
25. (a) Abdelhalim, A.; Falco, A.; Loghin, F.; Lugli, P.; Salmerón, J. F.; Rivadeneyra, A. In Flexible NH3 sensor based on spray deposition and inkjet printing, SENSORS, 2016 IEEE, IEEE: 2016; pp 1-3; (b) Falco, A.; Salmerón, J.; Loghin, F.; Abdelhalim, A.; Lugli, P.; Rivadeneyra, A. In Optimization of process parameters for inkjet printing of CNT random networks on flexible substrates, Nanotechnology (IEEE-NANO), 2016 IEEE 16th International Conference on, IEEE: 2016; pp 487-490.

26. Falco, A.; Rivadeneyra, A.; Loghin, F. C.; Salmerón, J. F.; Lugli, P.; Abdelhalim, A., Towards Low-Power Electronics: Self-Recovering and Flexible Gas Sensors. Journal of Materials Chemistry A 2018.

27. Albrecht, A.; Rivadeneyra, A.; Abdellah, A.; Lugli, P.; Salmerón, J. F., Inkjet Printing And Photonic Sintering of Silver and Copper Oxide Nanoparticles for Ultra-Low-Cost Conductive Patterns. Journal of Materials Chemistry C 2016, 4 (16), 3546-3554.

28. Abdellah, A.; Abdelhalim, A.; Loghin, F.; Kohler, P.; Ahmad, Z.; Scarpa, G.; Lugli, P., Flexible carbon nanotube based gas sensors fabricated by large-scale spray deposition. Sensors Journal, IEEE 2013, 13 (10), 4014-4021.

29. Colasanti, S.; Robbiano, V.; Loghin, F. C.; Abdelhalim, A.; Bhatt, V. D.; Abdellah, A.; Cacialli, F.; Lugli, P., Experimental and Computational Study on the Temperature Behavior of CNT Networks. IEEE Transactions on Nanotechnology 2016, 15 (2), 171-178.

30. Lin, Z.-D.; Young, S.-J.; Chang, S.-J., Carbon Nanotube Thin Films Functionalized Via Loading of Au Nanoclusters for Flexible Gas Sensors Devices. IEEE Transactions on Electron Devices 2016, 63 (1), 476-480. 
31. (a) Penza, M.; Rossi, R.; Alvisi, M.; Signore, M.; Cassano, G.; Dimaio, D.; Pentassuglia, R.; Piscopiello, E.; Serra, E.; Falconieri, M., Characterization of Metal-Modified and VerticallyAligned Carbon Nanotube Films for Functionally Enhanced Gas Sensor Applications. Thin Solid Films 2009, 517 (22), 6211-6216; (b) Star, A.; Joshi, V.; Skarupo, S.; Thomas, D.; Gabriel, J.-C. P., Gas Sensor Array Based on Metal-Decorated Carbon Nanotubes. The Journal of Physical Chemistry B 2006, 110 (42), 21014-21020.

32. Zhang, D.; Wang, K.; Tong, J.; Xia, B., Characterization of Layer-by-Layer Nano SelfAssembled Carbon Nanotube/Polymer Film Sensor for Ethanol Gas Sensing Properties. Microsystem technologies 2014, 20 (3), 379-385.

33. Zhao, H.; Zhang, T.; Qi, R.; Dai, J.; Liu, S.; Fei, T., Drawn on Paper: A Reproducible Humidity Sensitive Device by Handwriting. ACS applied materials \& interfaces 2017, 9 (33), 28002-28009.

34. Honda, W.; Harada, S.; Arie, T.; Akita, S.; Takei, K. In Printed wearable temperature sensor for health monitoring, IEEE SENSORS 2014 Proceedings, IEEE: 2014; pp 2227-2229. 
Realization of resistive CNT-based gas sensor on flexible substrate with a ball pen, exhibiting performance comparable to higher cost technologies. For its fabrication, both commercial and custom-made inks are employed, broadening the use of this technology. Such a solution provides a fast prototyping tool and opens the electronics - and the sensors world to the so-called do-it-yourself (DIY) paradigm

Ball pen, carbon nanotubes, flexible substrate, resistive sensor, silver nanoparticles

F. C. Loghin*, A. Falco, A. Albrecht, J. F. Salmerón, M. Becherer, P. Lugli, A. Rivandeneyra*

A handwriting method for low-cost gas sensors

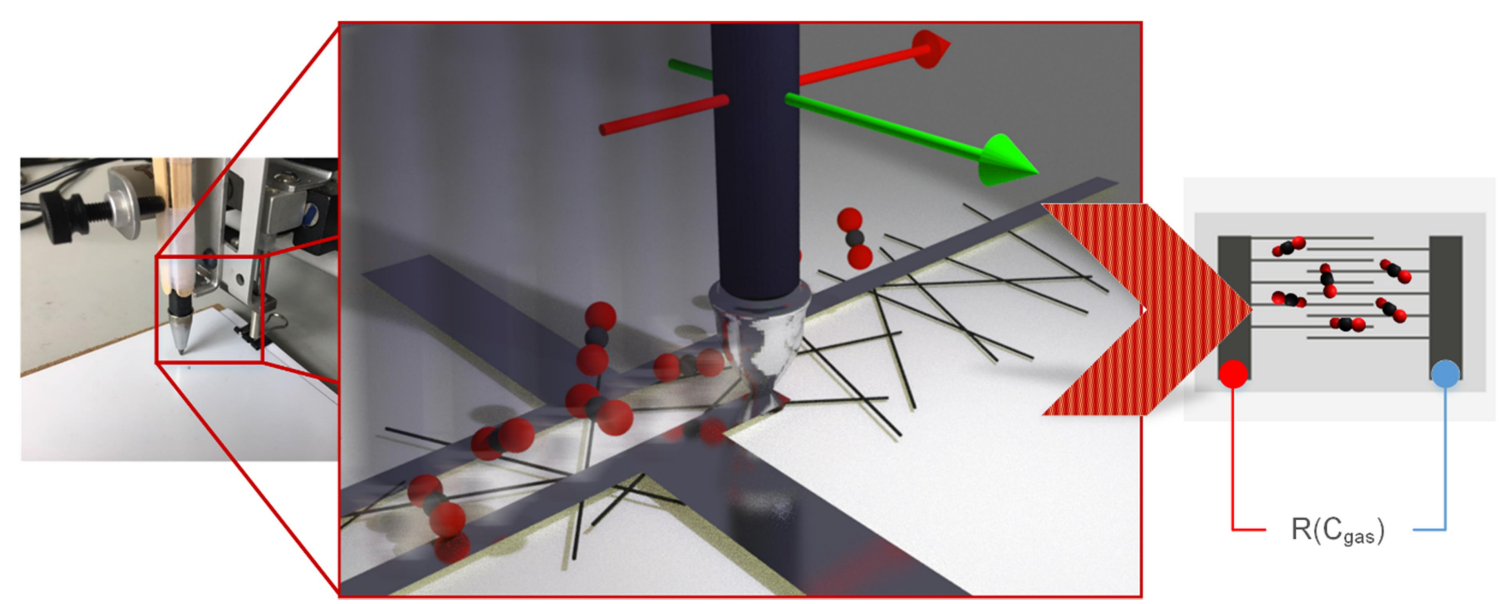




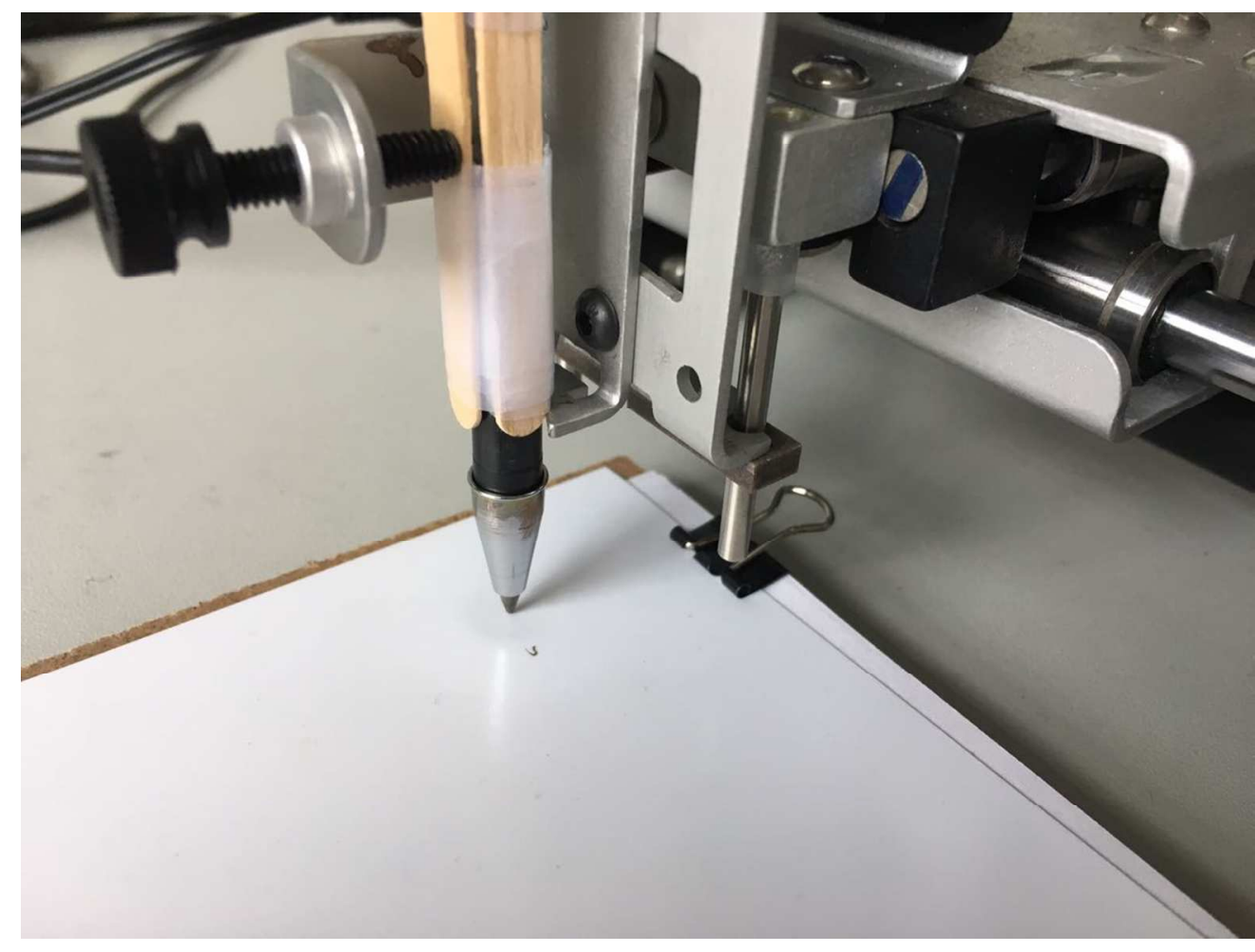

Figure 1. (a) Photograph of ball pen in the robot arm employed to develop the printed sensor $338 \times 254 \mathrm{~mm}(96 \times 96 \mathrm{DPI})$ 


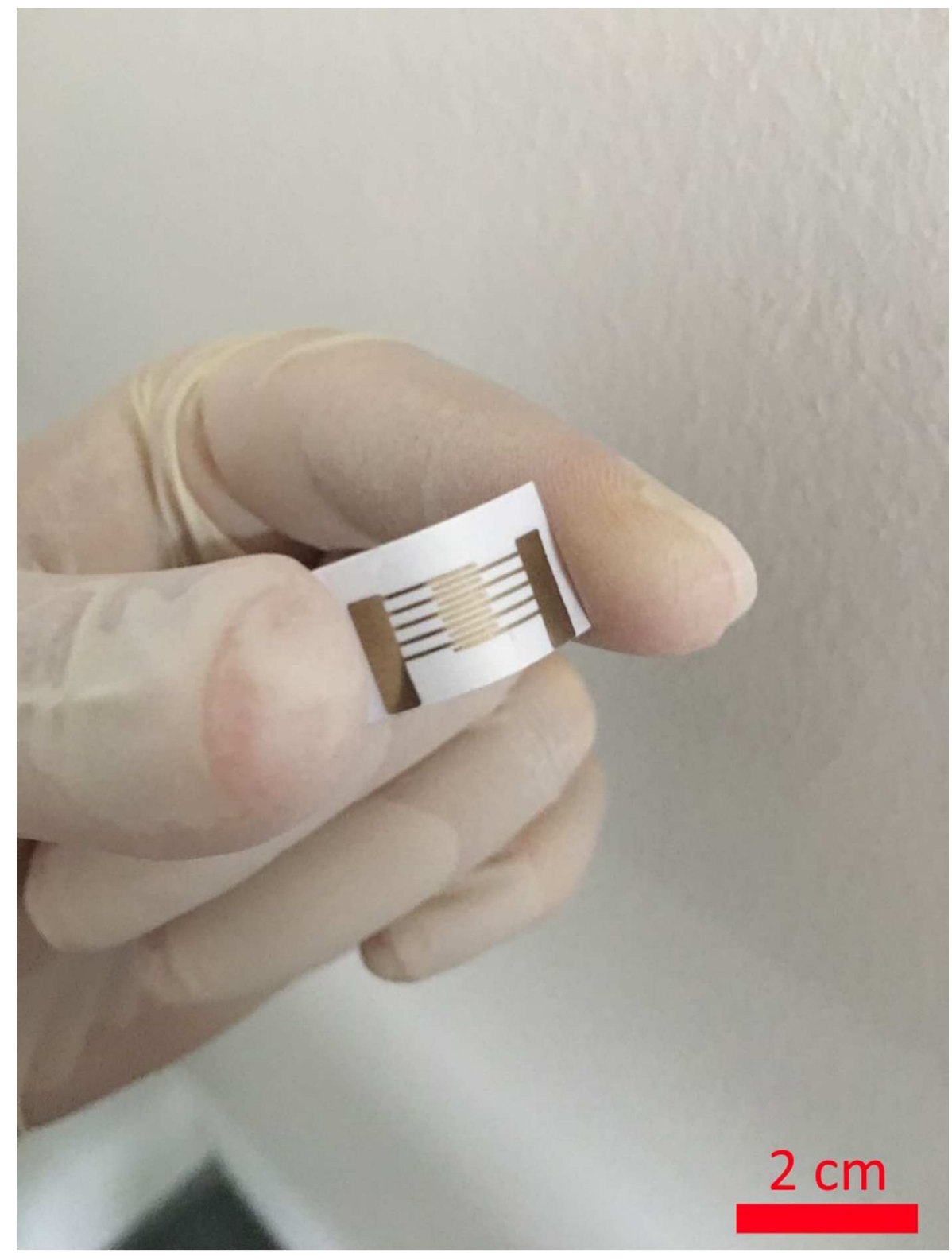

Figure 2. (a) Photograph of the fabricated sensor; $254 \times 338 \mathrm{~mm}(96 \times 96 \mathrm{DPI})$ 


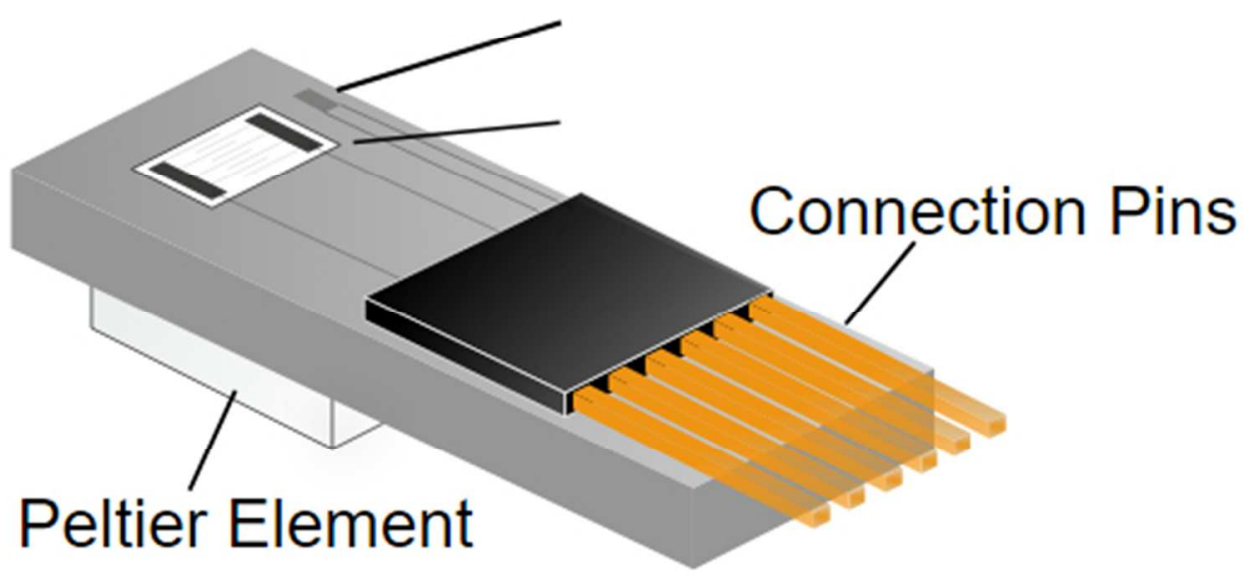

Figure 2. (b) schematic depicting the sensor module $143 \times 75 \mathrm{~mm}(96 \times 96 \mathrm{DPI})$ 

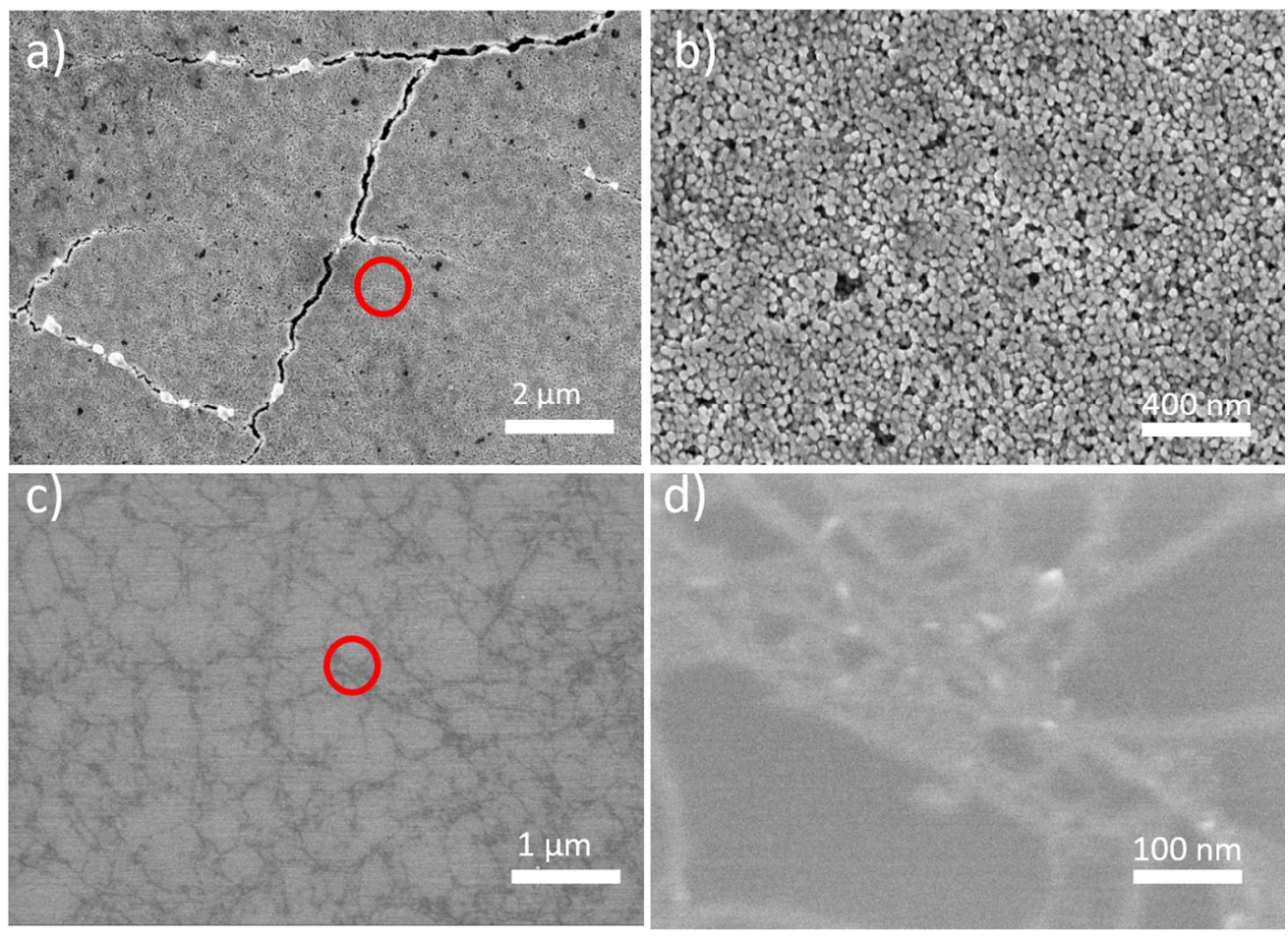

d)

Figure 3. (a-b) Scanning electron microscope image of the silver nanoparticle film at (a) $5 \mathrm{~K}(1 \mu \mathrm{m}$ scale) and (b) $25 \mathrm{~K}$ (200 nm scale bar) magnification with the red circle depicting the higher magnification region. (c-d) ) Scanning electron microscope image of the CNT film at (a) $20 \mathrm{~K}$ (1 $\mu \mathrm{m}$ scale) and (b) $200 \mathrm{~K}$ (100 nm scale bar) magnification with the red circle depicting the higher magnification region.

$364 \times 263 \mathrm{~mm}(96 \times 96 \mathrm{DPI})$ 
(a)
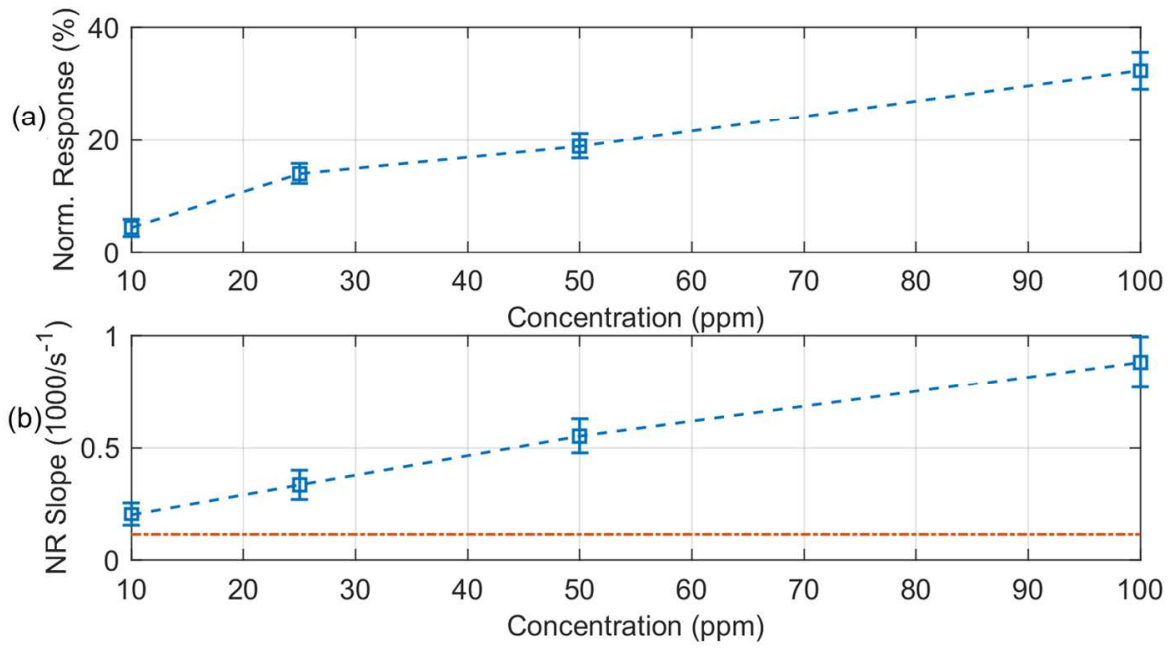

Figure 4. Response to $\mathrm{NH}_{3}$ (a) Normalized resistance vs. concentration; (b) Average slope of the normalized response in the first $150 \mathrm{~s}$ of exposure. The red dashed line indicates the average slope of the normalized response in the last $150 \mathrm{~s}$ of cooling time.

$499 \times 255 \mathrm{~mm}(96 \times 96$ DPI $)$ 
(a)
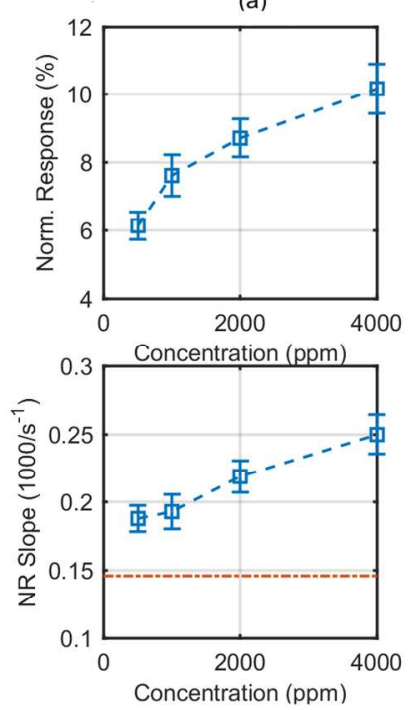

(b)
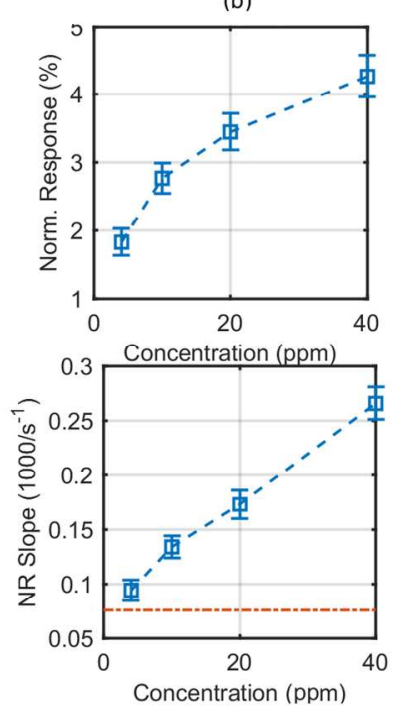

(c)
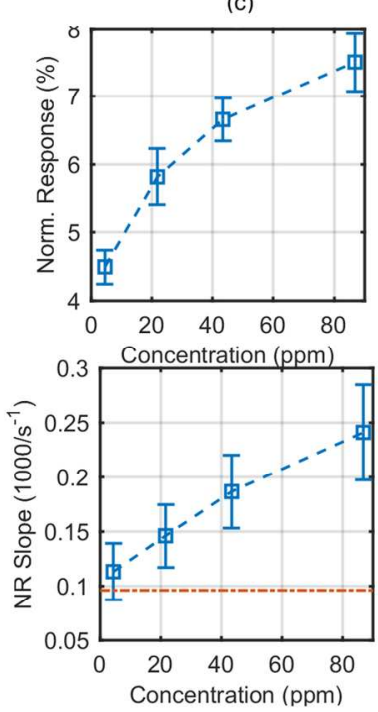

Figure 5. First row corresponds to the normalized resistance, bottom row to average slope of the normalized response in the first $150 \mathrm{~s}$ of exposure vs. concentration for (a) $\mathrm{CO}_{2}$, (b) $\mathrm{CO}$ and (c) Ethanol. In the bottom row the red dashed line indicates the average slope of the normalized response in the last $150 \mathrm{~s}$ of cooling time.

499×288mm (96 x 96 DPI) 
(a)

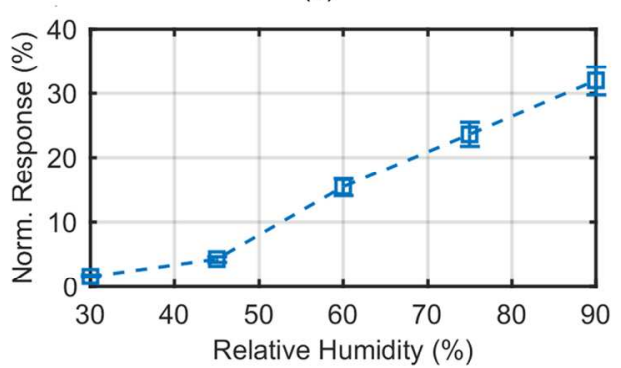

(b)

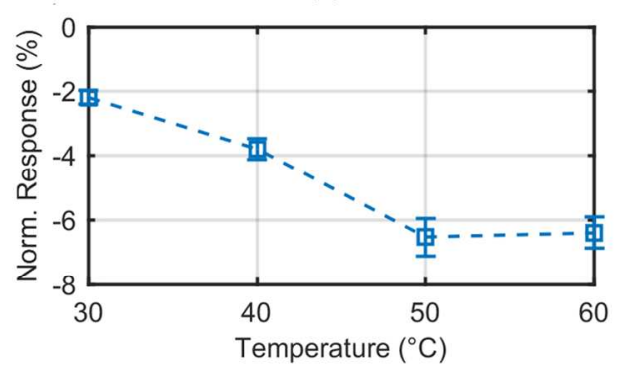

Figure 6. Normalized resistance vs. concentration for (a) RH and (b) Temperature.

$430 \times 139 \mathrm{~mm}(96 \times 96 \mathrm{DPI})$ 


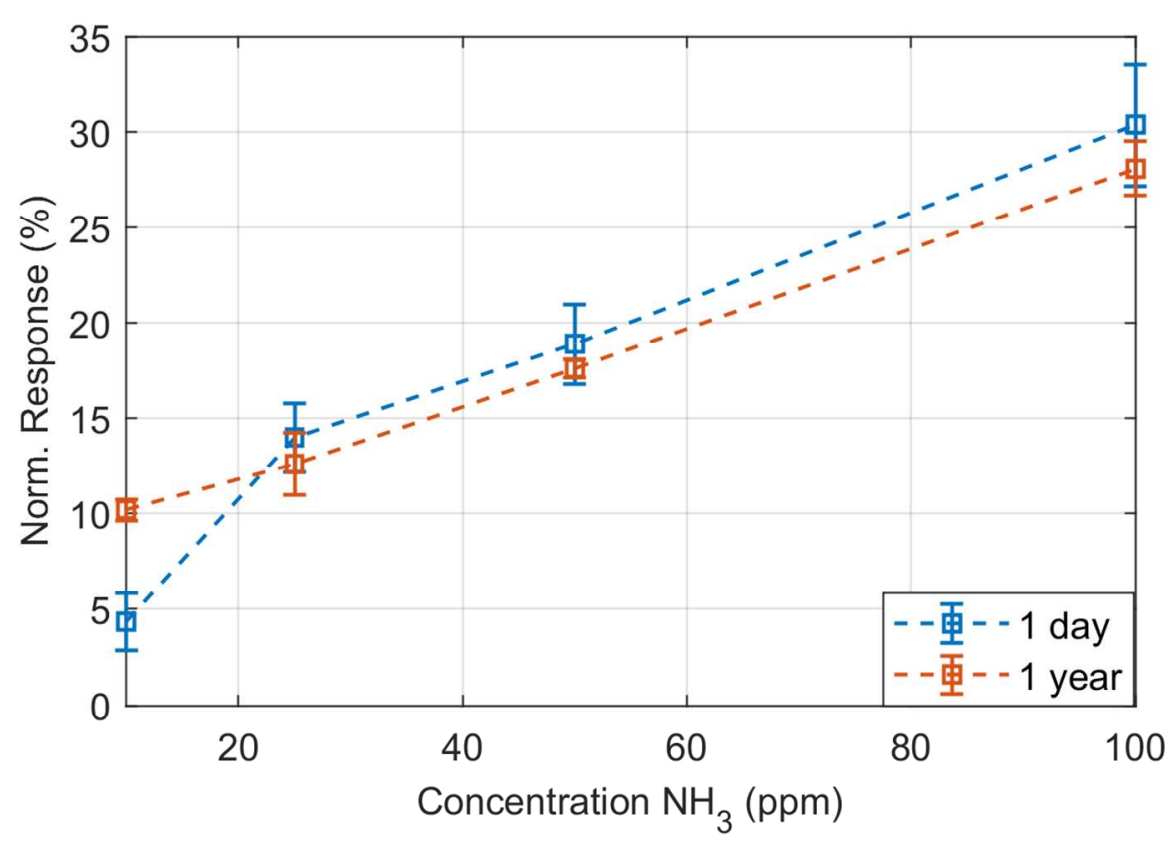

Figure 7. Normalized response with respect to different concentrations of $\mathrm{NH}_{3}$ for the same sensor one day after fabrication (blue line) and one year after fabrication (orange line).

$119 \times 80 \mathrm{~mm}(300 \times 300 \mathrm{DPI})$ 